\title{
Frontline healthcare workers' mental distress, top concerns, and assessment on hierarchy of controls in response to COVID-19: a cross-sectional survey study
}

Lingling Zhang ${ }^{1 *}{ }^{\circledR}$, Kimberlee L. Flike ${ }^{1}$, C. Ann Gakumo ${ }^{1}$, Ling Shi ${ }^{1}$, Suzanne G. Leveille ${ }^{1}$ and Linda S. Thompson ${ }^{2}$

\begin{abstract}
Background: The existing studies showed that frontline healthcare workers during an epidemic experienced unusual stressors and mental distress which even lasted for years after the crisis. It is important to learn about their concerns early to mitigate the negative impact as well as to evaluate disease control from experiences on the front lines for improving responses to the outbreak. The study aimed to provide insights on how to strengthen public health responses to protect healthcare workers both physically and mentally, and effectively control the disease in light of hierarchy of controls.

Methods: A cross-sectional survey was distributed online via Qualtrics to frontline healthcare workers during the COVID-19 through a university's nursing program and received 267 valid responses from 103 certificated nursing assistants, 125 nurses, and 39 other health professionals. A descriptive data analysis with a Chi-square test at a twosided 0.05 level of significance was performed on factors that potentially affected mental health of healthcare workers and effectiveness of disease control at workplace in five domains. The themes were summarized on open-ended questions.

Results: About 30\% of the respondents showed the symptom of depression and needed a further investigation. The influencing factors in five domains were examined. Engineering and administrative controls, as well as PPE were widely used in response to COVID-19. The respondents assessed the state and workplace responses to COVID-19 better than the federal government responses. The workplace responses were considered most effective. Multiple factors with a statistically significant correlation with effectiveness of the disease control at workplace were identified.

Conclusions: The study suggested that timely responses at policy level will be more effective than other measures in early prevention and control of the pandemic, mental distress should be addressed in addition to PPE, and nursing programs should consider providing a situation-specific career coaching or counseling for students. A longitudinal study at a larger scale is warranted to capture the variation of time change with the disease control evolvement and across geographic regions.
\end{abstract}

\footnotetext{
*Correspondence: lingling.zhang@umb.edu

${ }^{1}$ Department of Nursing, College of Nursing and Health Sciences,

University of Massachusetts Boston, 100 William T. Morrissey Blvd., Boston, MA 02125-3393, USA

Full list of author information is available at the end of the article
}

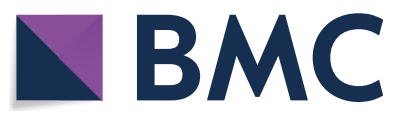

(c) The Author(s) 2021. Open Access This article is licensed under a Creative Commons Attribution 4.0 International License, which permits use, sharing, adaptation, distribution and reproduction in any medium or format, as long as you give appropriate credit to the original author(s) and the source, provide a link to the Creative Commons licence, and indicate if changes were made. The images or other third party material in this article are included in the article's Creative Commons licence, unless indicated otherwise in a credit line to the material. If material is not included in the article's Creative Commons licence and your intended use is not permitted by statutory regulation or exceeds the permitted use, you will need to obtain permission directly from the copyright holder. To view a copy of this licence, visit http://creativecommons.org/licenses/by/4.0/. The Creative Commons Public Domain Dedication waiver (http://creativeco mmons.org/publicdomain/zero/1.0/) applies to the data made available in this article, unless otherwise stated in a credit line to the data. 
Keywords: COVID-19, Healthcare workers, Mental distress, Hierarchy of controls, Workplace response

\section{Background}

Coronavirus disease 2019 (COVID-19) is an infectious disease caused by a newly discovered coronavirus, identified as severe acute respiratory syndrome coronavirus 2 (SAR-CoV-2), which is highly transmissible and threatens human health and public safety $[1,2]$. The outbreak of COVID-19 has affected almost every country around the world [3]. On the front lines of this pandemic are healthcare workers (HCWs) who continue to show up to work and come into close contact with patients with COVID19 [4] despite shortages of personal protective equipment (PPE) [5], exhaustion and uncertainty [6]. In Italy, up to $9 \%$ of HCWs were estimated to have contracted the virus [7]. In the United States (U.S.), among states with more complete reporting data, the number of COVID-19 infections among HCWs was up to $11 \%$, and is expected to continue rising [8]. As of early April 2021, more than 3600 HCWs had died of COVID-19 in the U.S. [9].

In comparison to past pandemics, SAR-CoV-2 has tricky and complex mechanisms that have facilitated its rapid and catastrophic spread worldwide [10]. Although the COVID-19 pandemic is commonly compared to the influenza pandemic of 1918 [11], more recent viral outbreaks, such as severe acute respiratory syndrome (SARS) in 2003, H1N1 influenza pandemic in 2009, and Ebola in 2014, have offered insights into the unusual stressors experienced by HCWs during these crises. Commonly cited stressors are the interference with family relationships [12-14], shortage of supplies [13, 15], heavy workloads [13, 15, 16], caring for an infected patient [17], and perceived threat [18], which have been linked to absenteeism [19], insomnia [17], and mental distress [12, 14] among HCWs.

A systematic review reported the significant mental impact of infectious disease outbreaks on HCWs, with the top three diagnoses being anxiety, depression, and acute stress disorder [20]. Others found post-traumatic stress symptoms among HCWs have persisted years after an outbreak [21]. These serious and persistent effects of viral outbreaks reported among HCWs require further exploration into the stress they experience. This study explored whether health professionals working on the front lines during COVID-19 showed symptoms of depression and how their concerns could be better addressed through the lens of their assessment on the responses to COVID-19 at workplace, state government, and federal government. It aimed to provide insights on how to strengthen public health responses to protect healthcare workers both physically and mentally, and effectively control the disease in light of hierarchy of controls.

\section{Methods \\ Design}

A cross-sectional survey study was conducted. An online questionnaire was developed in Qualtrics (a webbased survey tool for survey research, especially market research), and reviewed by content experts. A convenience sampling was used to distribute the survey via emails to all full-time and part-time nursing students enrolled in the nursing undergraduate and graduate programs at a university in Massachusetts (MA) state of the U.S.. The survey was open between April 10th and May 5th 2020, coinciding with the height of the initial wave of the pandemic in MA. Many of these nursing students were working on the front lines of the COVID-19 pandemic at different health care institutions across MA and beyond. Respondents could further disseminate the survey to their colleague if they were practicing health professionals and interested in taking the survey. Hence, the actual respondents were not limited to nursing students or nursing professionals. A general term health professionals or HCWs was used interchangeably in the paper. The survey lasted three and a half weeks with an email reminder.

The questionnaire consisted of 30 questions, including both close-ended and open-ended questions, which can be grouped into five domains: work characteristics, background characteristics, assessment on the responses taken at different levels, measures of disease prevention and control at workplace, and perceived needs. Both quantitative and qualitative data were analyzed in this study.

\section{Measures}

The survey evaluated HCWs' stressors, factors that were potentially related to the symptom of depression, measured by the Patient Health Questionnaire-2 (PHQ-2), which inquires about the degree to which an individual has experienced depressed mood and anhedonia [22]. PHQ-2 is a 2-item instrument that asks, "Over the last 2 weeks, how often have you been bothered by (1) little interest or pleasure in doing things" or (2) "feeling down, depressed or hopeless". For each of the 2 items, participants choose from the following 4 responses "Not at all", "Several days", "More than half the days", and "Nearly every day", scored 0 to 3 , respectively [23]. Scores on the 2 items are summed and the standard PHQ- 2 cut-point 
of $\geq 3$ was applied to identify depression (range 0 to 6) [24]. The purpose of PHQ-2 is not to establish final diagnosis or to monitor depression severity, but rather to screen for depression. Patients who screen positive should be further evaluated with the PHQ-9 or other diagnostic methods to determine whether they meet criteria for a depressive disorder [24]. Participants were asked to describe their major concerns regarding the pandemic in an open-ended question that allowed them to elaborate their experiences and opinions.

In conjunction with mental health impact of COVID19 , this study also investigated potentially modifiable factors through hierarchy of controls. Hierarchy of controls has traditionally been used as a means of determining how to implement feasible and effective control solutions [25]. It has five levels of controls in an upside down pyramid listing the measures from the most to the least effective from the top to the bottom. In the survey, participants were asked to assess if actions taken at the federal government, state government, and workplace to fight COVID-19 were helpful, timely, and effective.

As workplace was the factor affecting the respondents in the most direct way, it was particularly assessed to better understand what was happening on the front lines. Answers to the question about helpfulness of workplace responses used Likert scale as "Extremely helpful", "Very helpful", "Somewhat helpful", "Not so helpful", "Not at all helpful". Questions about if the workplace response was taken at a timely or effective manner were given answers as "Yes", "Neutral", "No". An open-ended question was provided to the participants to describe any special measure that has been taken at their workplace in response to the COVID-19 outbreak.

\section{Statistical analysis}

Data analysis was performed using Stata/SE version 15.1. Continuous variables were summarized descriptively using means and standard deviations, while categorical variables using counts and percentages. A Chi-square test was used to examine the association of factors in five domains with depression and with workplace effectiveness. Statistical tests were conducted at a two-sided 0.05 level of significance. As the statistical tests were not for inferential or confirmatory testing purpose, no adjustment for multiplicity of testing was conducted.

\section{Qualitative analysis}

Open-ended questions were provided to the participants to enter free text about their opinions. Qualitative data analysis was conducted using the content analysis to identify emerging themes. The narrative answers to these questions were reviewed and coded for recurrent themes independently by two researchers. They cross-checked each other's coding and achieved an agreement on the themes.

\section{Ethics}

The study protocol was reviewed by the University's Institutional Review Board (IRB) and determined to be exempt (study number \#2020084). The participants were deemed to give the consent to use the data for research purpose if they proceeded with the survey. The data were kept confidential and no personally identifiable information was reported.

\section{Results}

There were 271 participants that completed the survey with $98.52 \%$ valid responses. The majority of the respondents were nursing professionals, among which, 38.58\% of them were Certified Nursing Assistants (CNAs) and $46.82 \%$ of them were nurses with a variety of specialties. Compared to nurses, CNAs typically have limited nursing education primarily related to personal care of sick or disabled people. Other participants (14.61\%) were physicians, phlebotomists, emergency medical technicians, lab technicians, transport aides, pharmacists, etc. About $90 \%$ of the respondents were currently seeing patients, $75.28 \%$ of them worked in a hospital setting, and 78.49\% of them were practicing in MA. As the survey was mainly distributed to nursing students, the participants tended to be young and had less work years. Over $93 \%$ of them had someone live in the same household which elevated the risk of infection. Table 1 reports the characteristics of participants.

\section{Responses related to participants' mental health and top concerns \\ PHQ-2}

To use the cut-point of PHQ- $2 \geq 3$, about $30 \%$ of the respondents showed the symptom of depression implying that they would need a further investigation. There were several factors in the study identified to be significantly associated with the symptom of depression through a Chi-square test, including job category $(p<0.05)$, level of PPE $(p<0.05)$, effectiveness of workplace responses $(p<0.05)$, shortage of health workers $(p<0.05)$, and workplace stress $(p<0.01)$.

\section{Top concerns of the participants}

The survey asked the respondents about their concerns from a list of issues in light of COVID-19. Three levels of answers were provided as "a lot", "a moderate amount" and "a little". The top concerns measured by the level of "a lot" from high to low by the number of respondents are illustrated in Fig. 1. The results showed that the participants had a major concern about uncertainty of the 
Table 1 Characteristics of the sample

\begin{tabular}{|c|c|}
\hline Characteristics & $N(\%)$ \\
\hline \multicolumn{2}{|l|}{ Job category } \\
\hline CNA & $103(38.58)$ \\
\hline Nurse & $125(46.82)$ \\
\hline Physicians and pharmacists & $15(5.62)$ \\
\hline Other & $24(8.99)$ \\
\hline \multicolumn{2}{|l|}{ Work setting } \\
\hline Hospital & $201(75.28)$ \\
\hline Community & $27(10.11)$ \\
\hline Nursing home & $20(7.49)$ \\
\hline Other & $19(7.12)$ \\
\hline \multicolumn{2}{|l|}{ Currently seeing patients } \\
\hline Yes & $238(89.14)$ \\
\hline No & $29(10.86)$ \\
\hline \multicolumn{2}{|l|}{ Work years } \\
\hline$<1$ year & $69(25.84)$ \\
\hline $1-5$ years & $138(51.69)$ \\
\hline $6-10$ years & $39(14.61)$ \\
\hline $11-15$ years & $9(3.37)$ \\
\hline$\geq 16$ years & $12(4.49)$ \\
\hline \multicolumn{2}{|l|}{ Have children } \\
\hline Yes & 75 (28.09) \\
\hline No & $192(71.91)$ \\
\hline \multicolumn{2}{|l|}{ Have a housemate } \\
\hline Yes & $249(93.26)$ \\
\hline No & $18(6.74)$ \\
\hline \multicolumn{2}{|l|}{ Age } \\
\hline 25 and under & $94(35.21)$ \\
\hline $26-35$ & $108(40.45)$ \\
\hline $36-44$ & $39(14.61)$ \\
\hline $45-54$ & $15(5.62)$ \\
\hline 55 and above & $11(4.12)$ \\
\hline \multicolumn{2}{|l|}{ Marital status } \\
\hline Married & $94(35.21)$ \\
\hline Never married & $160(59.93)$ \\
\hline Other & $13(4.87)$ \\
\hline \multicolumn{2}{|l|}{ Race/ethnicity } \\
\hline White & $184(68.91)$ \\
\hline Black or African & $27(10.11)$ \\
\hline Asian & $27(10.11)$ \\
\hline Other (including Hispanic) & $29(10.86)$ \\
\hline \multicolumn{2}{|l|}{ State } \\
\hline MA & $208(78.49)$ \\
\hline Other & $57(21.51)$ \\
\hline
\end{tabular}

pandemic including its duration and the knowledge about it, spread of the disease to their family members, and health care system capacity. They were also concerned about the information transparency, public awareness of the disease, and their health safety at work.
There were relatively less financial concerns about the compensation policy and their personal health care costs related to COVID-19 infection.

To learn about the concerns of health professionals in depth and more extensively, an open-ended question about the top concern related to COVID-19 was asked. Four themes emerged from their descriptions.

First, the concern about the transmission to self or others was mostly mentioned, by about $64.4 \%$ of respondents. They were deeply worried about passing the virus to their family, given the fact that over $93 \%$ of them have a housemate. They were also concerned about the transmission to patients, coworkers, and themselves.

Second, the lack of equipment such as PPE was deeply concerning by about $34 \%$ of respondents, which was due to the reality of shortage as well as to the changing rules in infection control.

Third, about $25.6 \%$ of the participants also expressed concerns about the fluid protocols and need of systemic responses to the pandemic to address issues such as not following guidelines, testing, overwhelming system, changes to system for non-COVID patients, etc.

Fourth, about $15.7 \%$ of the participants were concerned about long-term impact, such as mental health, uncertainty, economic effect, etc.

\section{Responses related to COVID-19 control Hierarchy of controls}

Figure 2 illustrated the hierarchy of controls adapted to this study with examples showing corresponding actions on the front lines. The control methods at the top of the pyramid are potentially more effective and protective than those at the bottom [25]. While elimination and substitution are not yet possible for removing and replacing the hazard (i.e., COVID-19), respectively, engineering controls can be implemented at the current stage to isolate people from the hazard. Administrative controls are the next along the path that should be used to change the way people work. If the worker's risk of exposure is not eliminated at the source and along the path, then controls at the worker level can be put in place [26]. Other than PPE, mental resilience should be added to the personal level protection. All three levels of controls at the bottom (i.e., engineering controls, administrative controls, and $\mathrm{PPE}$ ) are currently co-existing in response to COVID-19, according to the participants' descriptions.

The responses to COVID-19 at the federal government, state government, and workplace were examined as three levels of disease control administration in practice which applied a mix of three levels of controls stated above and were assessed from the aspects of helpfulness, timeliness, and effectiveness. The results showed that the respondents considered the actions from more to less effective 


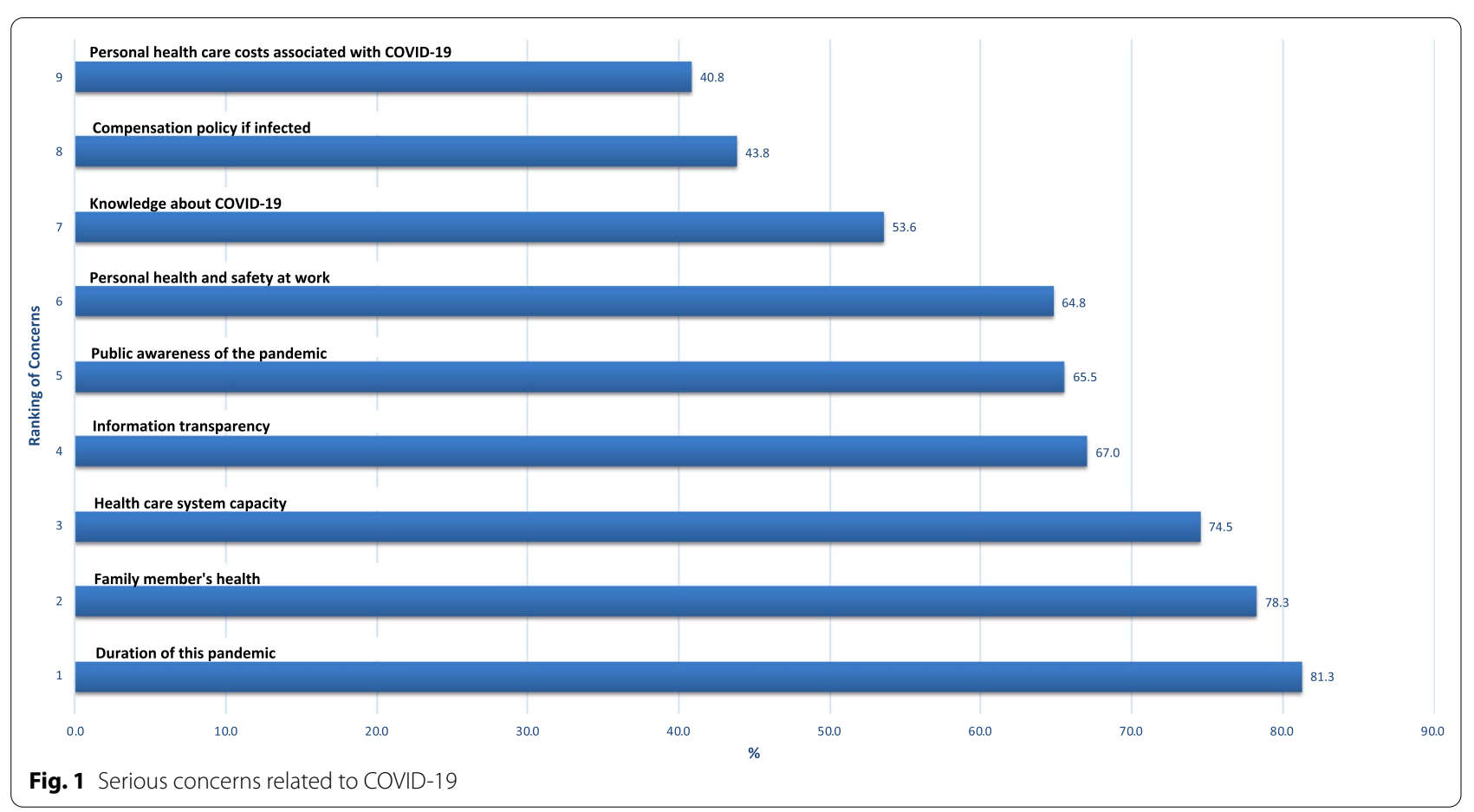

\begin{tabular}{|c|c|c|c|}
\hline & \multicolumn{3}{|c|}{ Hierarchy of Controls } \\
\hline & \multirow[b]{2}{*}{$\begin{array}{l}\text { Elimination } \\
\text { Substitution }\end{array}$} & \multicolumn{2}{|c|}{ Existing controls in response to COVID-19 } \\
\hline & & $\begin{array}{l}\text { Engineering } \\
\text { Controls }\end{array}$ & $\begin{array}{l}\text { e.g. COVID-19 unit, restrictions of visitors, } \\
\text { outside tent, temperature checks, hotel } \\
\text { rooms for staff }\end{array}$ \\
\hline & $\begin{array}{l}\text { Engineering } \\
\text { Controls }\end{array}$ & $\begin{array}{l}\text { Administrative } \\
\text { Controls }\end{array}$ & $\begin{array}{l}\text { e.g. telemedicine, longer shifts, increased } \\
\text { communications, decreased documentation } \\
\text { requirement, limited surgeries }\end{array}$ \\
\hline & & PPE & $\begin{array}{l}\text { in use; suggest to add "build mental } \\
\text { resilience" }\end{array}$ \\
\hline
\end{tabular}

in the order of the workplace (54.68\%), state government (46.07\%), and federal government (17.29\%). The similar pattern was revealed for the evaluation on helpfulness and timeliness of responses. In relating the responses to the PHQ-2 outcomes, those who considered the federal government neither timely nor effective were more likely to be depressive than those who considered the same for the state government and workplace. The possible interpretation was they tended to perceive the responses at the level closer to them better as they were more directly affected by those responses, although the association was not statistically significant. The assessment on the effectiveness of workplace responses to COVID-19, which seems to be the major protector for HCWs, was statistically correlated to PHQ-2 $(p<0.05)$ and further analyzed next.

\section{Assessment of workplace responses}

Among 267 valid responses about if their workplace responses to COVID-19 were helpful to address their concerns, $10.86 \%$ of them thought extremely helpful, $39.70 \%$ thought very helpful, $39.33 \%$ thought somewhat helpful, $7.87 \%$ thought not so helpful, and $2.25 \%$ thought not at all helpful. The participants were further asked to evaluate if their workplace took timely actions in response to COVID-19. The results from 266 valid responses showed that $52.63 \%$ of them thought "yes", $33.83 \%$ were "neutral", and "13.53\%" answered "no". 
The effectiveness was the core criteria to assess workplace responses. From 267 respondents, 54.68\% of them confirmed the actions effective, $36.70 \%$ held neutral opinion, and $8.61 \%$ said "no". The descriptive statistics of the data with the Chi-square test for influencing factors in five domains related to the effectiveness were examined (Table 2). A variety of factors were significantly correlated with the effectiveness of workplace responses, including work years, marital status, helpfulness, timeliness and effectiveness of federal government responses and state government responses, helpfulness and timeliness of workplace responses, workplace coping measures such as PPE, patient education, stress management for HCWs and patients, shortage of medical supplies and beds.

\section{Descriptions of workplace responses}

To better understand the situation at the front lines, the respondents were asked open-ended questions to describe what was happening at work to fight the pandemic. In their description about any special measure that has been taken at their workplace in response to the outbreak, seven themes were revealed as below:

1) $P P E$ There was an increased use of PPE, but in the meantime, the shortage of it was pointed out.

2) Restrictions, including visitor restrictions, social distancing, limited elective procedure and surgeries, symptom questionnaires and temperature checks before a shift, as well as limit contact with others outside of work.

3) Structural changes, such as creating COVID-19 only units, increasing negative pressure rooms, triaging and screening tents outside of ER, transferring equipment to other hospitals as needed.

4) Care delivery and communication The participants mentioned about the adoption of telemedicine and telephone triage, increased communication from management, working from home to minimize exposure, PPE training, and decreased documentation requirements.

5) Staffing changes, for example, working in teams. Nurses were being trained to work as back up to other departments. The scheduling included more shifts, overtime, longer shifts, and one week one off model. The ratio between patients and nurses increased.

6) New policies There were new situations associated with COVID patients so new policies were needed to cope with the challenges, such as the triage protocol, new code blue policies (i.e., new policies related to $\mathrm{CPR}$ ), no nebulizers or aerosolizing procedures available to follow, portable imaging. As the situation was fluid, there were constant changes to policies and procedures as described by a participant.

7) Additional support To reduce the fear of HCWs bringing the virus home, some workplaces offered hotel rooms for them. Other supporting efforts included providing resources for stress management, creating a serene space for employees who needed mindfulness moments, and reminding health professionals to protect themselves first.

Their comments were summarized by the themes and illustrated with the exemplar quotes in Table 3. Participants were also asked to describe any other actions besides PPE that were taken at their workplace to reduce their exposure to infection. They listed actions such as parking space offered by the hospital to reduce the use of public transit, reinforced education and detailed instructions, extended the length of shift, used extra disinfectants, provided rapid testing on site, and so on.

\section{Discussion}

MA has been one of the hardest hit states in the U.S., according to the State government. The survey was conducted during the surge of the COVID-19 in MA where the confirmed cases increased from 20,974 on April 10th to 70,271 on May 5th [27]. On April 18th, the positive cases reported in MA were just behind New York and New Jersey and became the top 3 states with the most confirmed cases of coronavirus per $100 \mathrm{~K}$ population in the country with the prediction of a peak in hospitalizations at the end of the month [28]. The non-essential business closures in MA started on March 23rd and were extended at the end of April. Against this backdrop, there were about one-third of the surveyed participants showed the symptom of depression which deserves an immediate attention. As reported, HCWs infected by SARS were at $40.7 \%$ increased risk of post-traumatic stress disorder (PTSD) [29], while those cared for SARS patients but were not infected continued to experience substantial long-term psychological distress [30, 31]. At the institution level, it is important to recognize the workplace stressors and address them, such as reducing burnout [32] and strengthening emergency preparedness for disease outbreak [33, 34]. To individual HCWs, besides support lines and a meditation remedy [35], more tailored programs should be in place to proactively help them undergo psychological adaptation [18] and cope with stress, such as the Stress Management and Resiliency Training (SMART) Program [36]. For instance, $38.6 \%$ respondents were CNAs from the undergraduate nursing program who are at the early stage of their career. This pandemic may affect their career choice in either direction, in terms of affirmation or quit. A previous 
Table 2 Descriptive statistics of selected influencing factors on workplace responses

\begin{tabular}{|c|c|c|c|c|}
\hline \multirow[t]{2}{*}{ Work characteristics } & \multirow{2}{*}{$\begin{array}{l}\text { Effective } \\
\text { Yes } \\
N(\%)\end{array}$} & \multirow{2}{*}{$\begin{array}{l}\text { Effective } \\
\text { Neutral } \\
N(\%)\end{array}$} & \multirow{2}{*}{$\begin{array}{l}\text { Effective } \\
\text { No } \\
N(\%)\end{array}$} & \multirow[t]{2}{*}{$p$} \\
\hline & & & & \\
\hline Job category & & & & 0.190 \\
\hline $\mathrm{CNA}^{*}$ & $64(43.84)$ & $32(32.65)$ & $7(30.43)$ & \\
\hline Nurse & $58(39.73)$ & $52(53.06)$ & $15(65.22)$ & \\
\hline Physicians and pharmacists & $10(6.85)$ & $5(5.10)$ & $0(0.00)$ & \\
\hline Other & 14 (9.59) & $9(9.18)$ & $1(4.35)$ & \\
\hline \multicolumn{5}{|l|}{ Workyears } \\
\hline$<1$ & $41(28.08)$ & $25(25.51)$ & $3(13.04)$ & 0.044 \\
\hline $1-5$ & $73(50.00)$ & $49(50.00)$ & $16(69.57)$ & \\
\hline $6-10$ & $21(14.38)$ & $17(17.35)$ & $1(4.35)$ & \\
\hline $11-15$ & $3(2.05)$ & $6(6.12)$ & $0(0.00)$ & \\
\hline$\geq 16$ & $8(5.48)$ & $1(1.02)$ & $3(13.04)$ & \\
\hline \multirow[t]{2}{*}{ Demographic characteristics } & $\begin{array}{l}\text { Effective } \\
\text { Yes }\end{array}$ & $\begin{array}{l}\text { Effective } \\
\text { Neutral }\end{array}$ & $\begin{array}{l}\text { Effective } \\
\text { No }\end{array}$ & $p$ \\
\hline & $N(\%)$ & $N(\%)$ & $N(\%)$ & \\
\hline \multicolumn{5}{|l|}{ Marital status } \\
\hline Married & $40(27.40)$ & $43(43.88)$ & $11(47.83)$ & 0.038 \\
\hline Never married & $100(68.49)$ & $49(50.00)$ & $11(47.83)$ & \\
\hline Other & $6(4.11)$ & $6(6.12)$ & $1(4.35)$ & \\
\hline \multicolumn{5}{|l|}{ Practice state } \\
\hline MA & $119(82.07)$ & $69(71.13)$ & $20(86.96)$ & 0.075 \\
\hline Other & $26(17.93)$ & $28(28.87)$ & $3(13.04)$ & \\
\hline \multirow[t]{2}{*}{ Assessment } & $\begin{array}{l}\text { Effective } \\
\text { Yes }\end{array}$ & $\begin{array}{l}\text { Effective } \\
\text { Neutral }\end{array}$ & $\begin{array}{l}\text { Effective } \\
\text { No }\end{array}$ & $p$ \\
\hline & $N(\%)$ & $N(\%)$ & $N(\%)$ & \\
\hline \multicolumn{5}{|l|}{ Helpful: Federal Government ${ }^{* *}$} \\
\hline 1 & $4(2.74)$ & $0(0.00)$ & $0(0.00)$ & 0.028 \\
\hline 2 & 17(11.64) & 15(15.31) & $1(4.35)$ & \\
\hline 3 & $71(48.63)$ & $37(37.76)$ & $5(21.74)$ & \\
\hline 4 & $33(22.60)$ & $33(33.67)$ & $11(47.83)$ & \\
\hline 5 & $21(14.38)$ & 13(13.27) & $6(26.09)$ & \\
\hline \multicolumn{5}{|l|}{ Helpful: State Government ${ }^{* *}$} \\
\hline 1 & $17(11.64)$ & $5(5.10)$ & $0(0.00)$ & 0.001 \\
\hline 2 & $43(29.45)$ & $21(21.43)$ & $1(4.35)$ & \\
\hline 3 & $70(47.95)$ & $56(57.14)$ & $14(60.87)$ & \\
\hline 4 & $11(7.53)$ & 14(14.29) & 4(17.39) & \\
\hline 5 & $5(3.42)$ & $2(2.04)$ & $4(17.39)$ & \\
\hline \multicolumn{5}{|l|}{ Helpful:workplace } \\
\hline 1 & $26(17.81)$ & $3(3.06)$ & $0(0.00)$ & 0.000 \\
\hline 2 & $80(54.79)$ & $26(26.53)$ & $0(0.00)$ & \\
\hline 3 & $36(24.66)$ & $61(62.24)$ & 8(34.78) & \\
\hline 4 & $4(2.74)$ & $6(6.12)$ & $11(47.83)$ & \\
\hline 5 & $0(0.00)$ & $2(2.04)$ & $4(17.39)$ & \\
\hline \multicolumn{5}{|l|}{ Timely: Federal Government } \\
\hline Yes & 23(15.86) & $8(8.16)$ & 3(13.04) & 0.032 \\
\hline Neutral & $50(34.48)$ & $37(37.76)$ & $2(8.70)$ & \\
\hline No & $72(49.66)$ & $53(54.08)$ & 18(78.26) & \\
\hline
\end{tabular}


Table 2 (continued)

\begin{tabular}{|c|c|c|c|c|}
\hline Assessment & $\begin{array}{l}\text { Effective } \\
\text { Yes } \\
N(\%)\end{array}$ & $\begin{array}{l}\text { Effective } \\
\text { Neutral } \\
N(\%)\end{array}$ & $\begin{array}{l}\text { Effective } \\
\text { No } \\
N(\%)\end{array}$ & $p$ \\
\hline \multicolumn{5}{|l|}{ Timely: State Government } \\
\hline Yes & $77(53.10)$ & $23(23.47)$ & $6(26.09)$ & \multirow[t]{3}{*}{0.000} \\
\hline Neutral & $58(40.00)$ & $56(57.14)$ & $3(13.04)$ & \\
\hline No & $10(6.90)$ & 19(19.39) & $14(60.87)$ & \\
\hline \multicolumn{5}{|l|}{ Timely: workplace } \\
\hline Yes & $115(79.31)$ & $23(23.47)$ & $2(8.70)$ & \multirow[t]{3}{*}{0.000} \\
\hline Neutral & $27(18.62)$ & $61(62.24)$ & $2(8.70)$ & \\
\hline No & $3(2.07)$ & 14(14.29) & 19(82.61) & \\
\hline \multicolumn{5}{|c|}{ Effective: Federal Government } \\
\hline Yes & $34(23.45)$ & 10(10.20) & $2(8.70)$ & \multirow[t]{3}{*}{0.006} \\
\hline Neutral & $57(39.31)$ & $42(42.86)$ & $5(21.74)$ & \\
\hline No & $54(37.24)$ & $46(46.94)$ & $16(69.57)$ & \\
\hline \multicolumn{5}{|c|}{ Effective: State Government } \\
\hline Yes & $92(63.01)$ & $27(27.55)$ & $4(17.39)$ & \multirow[t]{3}{*}{0.000} \\
\hline Neutral & $\begin{array}{l}43(29 \\
0.45)\end{array}$ & $58(59.18)$ & $6(26.09)$ & \\
\hline No & $11(7.53)$ & 13(13.27) & 13(56.52) & \\
\hline \multirow[t]{2}{*}{ Workplace measures } & $\begin{array}{l}\text { Effective } \\
\text { Yes }\end{array}$ & $\begin{array}{l}\text { Effective } \\
\text { Neutral }\end{array}$ & $\begin{array}{l}\text { Effective } \\
\text { No }\end{array}$ & \multirow[t]{2}{*}{$p$} \\
\hline & $N(\%)$ & $N(\%)$ & $N(\%)$ & \\
\hline \multicolumn{5}{|l|}{ PPElevel } \\
\hline Enough & 89(61.38) & $26(26.53)$ & $1(4.35)$ & \multirow[t]{3}{*}{0.000} \\
\hline Just OK & 48(33.10) & $49(50.00)$ & $6(26.09)$ & \\
\hline Not enough & $8(5.52)$ & $23(23.47)$ & 16(69.57) & \\
\hline \multicolumn{5}{|l|}{ Beyond PPE } \\
\hline Yes & $97(67.36)$ & $55(56.70)$ & $7(30.43)$ & \multirow[t]{2}{*}{0.002} \\
\hline No & $47(32.64)$ & $42(43.30)$ & $16(69.57)$ & \\
\hline \multirow[t]{2}{*}{ Perceived needs } & $\begin{array}{l}\text { Effective } \\
\text { Yes }\end{array}$ & $\begin{array}{l}\text { Effective } \\
\text { Neutral }\end{array}$ & $\begin{array}{l}\text { Effective } \\
\text { No }\end{array}$ & \multirow[t]{2}{*}{$p$} \\
\hline & $N(\%)$ & $N(\%)$ & $N(\%)$ & \\
\hline \multicolumn{5}{|l|}{ Absent: patient education } \\
\hline Yes & $20(13.70)$ & $24(24.49)$ & 13(56.52) & \multirow[t]{3}{*}{0.000} \\
\hline Maybe & $41(28.08)$ & 45(45.92) & $7(30.43)$ & \\
\hline No & $85(58.22)$ & $29(29.59)$ & $3(13.04)$ & \\
\hline \multicolumn{5}{|c|}{ Absent: stress management for healthcare workers } \\
\hline Yes & $43(29.45)$ & $53(54.08)$ & $14(60.87)$ & \multirow[t]{3}{*}{0.000} \\
\hline Maybe & 49(33.56) & $26(26.53)$ & $3(13.04)$ & \\
\hline No & $54(36.99)$ & 19(19.39) & 6(26.09) & \\
\hline Absent: stress managem & & & & \\
\hline Yes & 47(32.19) & 49(50.00) & $12(52.17)$ & 0.008 \\
\hline Maybe & $59(40.41)$ & 38(38.78) & $6(26.09)$ & \\
\hline No & $40(27.40)$ & $11(11.22)$ & $5(21.74)$ & \\
\hline Shortage: medical suppl & & & & \\
\hline Yes & $83(56.85)$ & $65(66.33)$ & 19(82.61) & 0.011 \\
\hline Maybe & $31(21.23)$ & $24(24.49)$ & $4(17.39)$ & \\
\hline No & $32(21.92)$ & 9(9.18) & $0(0.00)$ & \\
\hline
\end{tabular}


Table 2 (continued)

\begin{tabular}{|c|c|c|c|c|}
\hline \multirow[t]{2}{*}{ Perceived needs } & \multirow{2}{*}{$\begin{array}{l}\text { Effective } \\
\text { Yes } \\
N(\%)\end{array}$} & \multirow{2}{*}{$\begin{array}{l}\text { Effective } \\
\text { Neutral } \\
N(\%)\end{array}$} & \multirow{2}{*}{$\begin{array}{l}\text { Effective } \\
\text { No } \\
N(\%)\end{array}$} & \multirow[t]{2}{*}{$p$} \\
\hline & & & & \\
\hline \multicolumn{5}{|c|}{ Shortage: health workers } \\
\hline Yes & $65(44.52)$ & $55(56.12)$ & $16(69.57)$ & \multirow[t]{3}{*}{0.073} \\
\hline Maybe & $37(25.34)$ & $21(21.43)$ & $1(4.35)$ & \\
\hline No & $44(30.14)$ & $22(22.45)$ & $6(26.09)$ & \\
\hline \multicolumn{5}{|l|}{ Shortage: beds } \\
\hline Yes & $46(31.51)$ & 48(48.98) & $9(39.13)$ & \multirow[t]{3}{*}{0.038} \\
\hline Maybe & $42(28.77)$ & $26(26.53)$ & $4(17.39)$ & \\
\hline No & $58(39.73)$ & $24(24.49)$ & $10(43.48)$ & \\
\hline
\end{tabular}

*Certified nursing assistant

**1 $=$ extremely helpful, $2=$ very helpful, $3=$ somewhat helpful, $4=$ not so helpful, $5=$ not at all helpful

Table 3 Example responses regarding special measures taken at workplace in response to the COVID-19 outbreak

Personal protective equipment (PPE) (63\%)

"Everyone in hospital must wear a mask, to avoid transmission to each other, as social distancing doesn't work when you work together to take care of patients." Restrictions (48\%)

"The hospital has placed strict restrictions on who is allowed to come onto the premises. No visitation is allowed and no trainees/unnecessary personal are allowed either."

Structural changes (19\%)

"We have dedicated certain spaces to covid/covid rule out patients. Covid/covid rule out patients are triaged in a specific area and the sent to a designated area to be treated (unless there is overflow). We have HEPA filters in rooms that are not negative pressure for patients who are receiving aerosolizing procedures. Inpatient floors have been converted into ICUs to take over flow."

Care delivery and communication (18\%)

"We are only seeing patients through telehealth and ordering cardiology tests (stress echo, ct angiograms) based on urgency."

Staffing changes (15\%)

"Patient ratios have increased. Step-down nurses are now taking 5 patients (previously 3 or

4) and ICU nurses are always taking 2 (previously 1 or 2), although we've been told those ratios may increase further."

New policies $(6 \%)$

"There has been no neb or CPAP/BiPAP and patients are left with the decision to be intubated or risk death due to respiratory compromise with littler interventions. Conversations have occurred about allocation of resources and potential termination of mechanical ventilation of patients to transfer vent to other patient if situation becomes. It's critical."

Additional support (3\%)

"Fear of healthcare professionals bringing the virus into their own households. To prevent this, the hospital has worked with hotels to provide people with certain circumstances the ability to stay at the hotel for free or discounted prices."

The responses are from 267 participants. There are overlapped responses

study showed that students' level of commitment to nursing programs could be harmed by high levels of experienced stress [37]. External support and putting HCWs first in fighting with infectious disease could attribute to their decisions in continuing nursing career. Further, improving job satisfaction of nurses can positively influence their professional commitment, in terms of willingness to make an effort, appraisal in continuing nursing career, and belief in goals and values [38].

Respondents who were less likely to have a symptom of depression were those being a nurse, considering workplace responses effective, having enough PPE, and perceived no shortage of HCWs. In contrast, CNA respondents, considering workplace responses somewhat effective, having just ok PPE, perceived shortage of HCWs at their workplace were more likely to have a symptom of depression.

The full hierarchy of comprehensive infection control measures has been recommended to protect HCWs [39]. The survey results showed that engineering and administrative controls, as well as PPE were widely used in response to COVID-19. The assessment on the state and workplace responses was better than the federal government responses. The workplace responses were considered most effective. Adaptation to change with the implementation of telemedicine during the pandemic was a good example. Future disease prevention and control with early responses and consistent standards of 
implementation from policies could utilize elimination and substitution measures to benefit from more effective control methods.

Those who perceived the absence of stress management for patients and the shortage of medical supplies and HCWs were likely to consider workplace responses "effective", which seemed counter-intuitive. A possible explanation was the fact that the demand for patient-level intervention and more HCWs existed even without the pandemic $[40,41]$. As the respondents may have adapted to the reality, they were less likely to count those existing factors toward the responses to the new disease outbreak. The other explanation was with respect to the absence and shortages, the respondents thought their workplace still managed COVID-19 effectively. In addition, those working 1-5 years and never being married were more likely to consider the workplace responses effective.

Both the descriptive statistics and comments by the respondents provided the insightful information about the actions taken in responses to COVID-19. The limitations included: (1) the cross-sectional survey provides frontline health professionals' opinions and what was happening at work only during the survey period; and (2) the outcomes of PHQ-2 and effectiveness of workplace responses have not been examined holding confounding factors constant. Therefore, the conclusion needs to be drawn with caution. More in-depth statistical analysis will be followed.

In addition, the survey did not capture job titles and duties which may influence perceived control of HCWs, especially nursing staff. The existing studies show that HCWs with more control tend to have less burnout and be more resilient facing the pandemic $[42,43]$. Further research can be conducted to examine the impact of this factor.

\section{Conclusions}

This study suggested that timely response at the policy level will be more effective in controlling the epidemic. For instance, consistent guidelines not only for hospitals, but also for the public on curbing the disease will help save more lives; the emergency preparedness protocols with standard procedures to follow will direct the fight against the pandemic in a more organized manner; and rigorous implementation of the hierarchy of control measures can improve HCWs' protection from infection. PPE as an important physical protection should be coupled with actions addressing mental distress of HCWs. Universities with a nursing program should consider providing a situation-specific career coaching or counseling for students. Furthermore, a longitudinal study at a larger scale is warranted to capture the variation with the time change and across geographic regions. Persistent health education before, during, or after the pandemic is expected to bring enduring benefit to families, communities, and the country at large.

\section{Abbreviations}

COVID-19: Coronavirus disease 2019; HCWs: Healthcare workers; PPE: Personal protective equipment; U.S.: United States; SARS: Severe acute respiratory syndrome; MA: Massachusetts; PHQ-2: Patient Health Questionnaire-2; CNA: Certified nursing assistant.

\section{Acknowledgements}

We would like to thank the support from the College of Nursing and Health Sciences at University of Massachusetts Boston and all survey participants. We want to thank our colleagues Elizabeth L Donahoe, Liz Malone-O'Hara, Lourdes M Ortiz-Tapper, and Carlos Sala for their kind assistance.

\section{Authors' contributions}

$\mathrm{LZ}$ designed the study, analyzed the data, and wrote the manuscript. KF assisted in the questionnaire development, data collection and analysis, and manuscript development; CG contributed to the study design, data collection, and manuscript development; LS and SL contributed to the data analysis, result interpretation, and manuscript development; LT contributed to the conceptualization of the study, data collection and manuscript development, as well as served as the mentor author. All authors read and approved the final manuscript.

\section{Funding}

The study was supported by the College of Nursing and Health Sciences at University of Massachusetts Boston.

\section{Availability of data and materials}

The datasets during and/or analyzed during the current study are available from the corresponding author on reasonable request.

\section{Declarations}

\section{Ethics approval and consent to participate}

The study protocol was reviewed by the IRB at University of Massachusetts Boston (study number \#2020084) and determined to be exempt. The formal informed consent was waived by the IRB and the participants were considered to have an agreement on the study if they proceeded with the survey. The data were kept confidential and no personally identifiable information was reported.

\section{Consent for publication}

Not applicable.

\section{Competing interests}

The authors declare that they have no competing interests.

\section{Author details}

${ }^{1}$ Department of Nursing, College of Nursing and Health Sciences, University of Massachusetts Boston, 100 William T. Morrissey Blvd., Boston, MA 02125-3393, USA. ²Westfield State University, 577 Western Avenue, Westfield, MA 01086, USA.

Received: 20 January 2021 Accepted: 16 September 2021 Published online: 26 September 2021

References

1. Coronavirus. Who.int. https://www.who.int/health-topics/coronavirus. Accessed 3 Jun 2021

2. Hu B, Guo H, Zhou P, Shi Z-L. Characteristics of SARS-CoV-2 and COVID-19. Nat Rev Microbiol. 2021:19(3):141-54.

3. Centers for Disease Control and Prevention. Coronavirus disease 2019 (COVID-19): Global COVID-19. Atlanta (GA): Centers for Disease Control 
and Prevention; 2020 [updated 2020 July 28]. https://www.cdc.gov/coron avirus/2019-ncov/global-covid-19/world-map.html. Accessed 18 Sep 2020.

4. Ehrlich $\mathrm{H}$, McKenney M, Elkbuli A. Protecting our healthcare workers during the COVID-19 pandemic. Am J Emerg Med. 2020;38(7):1527-8. https://doi.org/10.1016/j.ajem.2020.04.024.

5. Livingston E, Desai A, Berkwits M. Sourcing personal protective equipment during the COVID-19 pandemic. JAMA. 2020;323(19):1912-4. https://doi.org/10.1001/jama.2020.5317.

6. Liu Q, Luo D, Haase J, Guo Q, Wang X, Liu S. The experiences of healthcare providers during the COVID-19 crisis in China: a qualitative study. Lancet Glob Health. 2020;8:1-9. https://doi.org/10.1016/S2214-109X(20) 30204-7.

7. International Council of Nurses. (2020, March 20). High proportion of health care workers with COVID-19 in Italy is a stark warning to the world: protecting nurses and their colleagues must be the number one priority. Geneve Switzerland: ICN; 2020. www.icn.ch/news/high-proportion-healt hcare-workers-covid-19-italy-stark-warning-world-protecting-nurses-and. Accessed 18 Sep 2020.

8. CDC COVID-19 Response Team. Characteristics of health care personnel with COVID-19-United States, February 12-April 9, 2020. MMWR Morb Mortal Wkly Rep. 2020;69(15):477-481. https://doi.org/10.15585/mmwr. mm6915e6.

9. Pitlik SD. COVID-19 compared to other pandemic diseases. Rambam Maimonides Med J. 2020;11(3): e0027.

10. The Staffs of KHN, The Guardian. Lost on the frontline: explore the database. Khn.org. 2021. https://khn.org/news/lost-on-the-frontline-explo re-the-database/. Accessed 3 Jun 2021.

11. Gates B. Responding to Covid-19-a once-in-a-century pandemic? N Engl J Med. 2020;382:1677-9. https://doi.org/10.1056/NEJMp2003762.

12. Imai H, Matsuishi $\mathrm{K}$, Ito A, Mouri K, Kitamura N, Akimoto K, et al. Factors associated with motivation and hesitation to work among health professionals during a public crisis: a cross sectional study of hospital workers in Japan during the pandemic (H1N1) 2009. BMC Public Health. 2010. https://doi.org/10.1186/1471-2458-10-672

13. Li Y, Wang $H$, Jin $X R$, Li $X$, Pender $M$, Song $C P$, et al. Experiences and challenges in the health protection of medical teams in the Chinese Ebola treatment center, Liberia: a qualitative study. Infect Dis Poverty. 2018;7(1):92. https://doi.org/10.1186/s40249-018-0468-6.

14. Maunder RG, Leszcz M, Savage D, Adam MA, Peladeau N, Romano D, et al Applying the lessons of SARS to pandemic influenza: an evidence-based approach to mitigating the stress experienced by healthcare workers. Can J Public Health. 2008;99(6):486-8. https://doi.org/10.1007/BF034 03782.

15. Funk DJ, Siddiqui F, Wiebe K, Miller RR, Bautista E, Jimenez E, et al. Practical lessons from the first outbreaks: clinical presentation, obstacles, and management strategies for severe pandemic (pH1N1) 2009 influenza pneumonitis. Crit Care Med. 2010;38(Suppl 4):e30-7. https://doi.org/10. 1097/CCM.0b013e3181d10522.

16. Wong EL, Wong SY, Lee N, Cheung A, Griffiths S. Healthcare workers' duty concerns of working in the isolation ward during the novel H1N1 pandemic. J Clin Nurs. 2012;21(9-10):1466-75. https://doi.org/10.1111/j. 1365-2702.2011.03783.x

17. Krupa S, Filip D, Mędrzycka-Dąbrowska W, Lewandowska K, Witt P, Ozga D. Sleep disorders among nurses and other health care workers in Poland during the COVID-19 pandemic. Appl Nurs Res. 2021;59: 151412.

18. Gázquez Linares JJ, Molero Jurado MDM, Martos Martínez Á, JiménezRodríguez D, Pérez-Fuentes MDC. The repercussions of perceived threat from COVID-19 on the mental health of actively employed nurses. Int J Ment Health Nurs. 2021. https://doi.org/10.1111/inm.12841.

19. Considine J, Shaban RZ, Patrick J, Holzhauser K, Aitken P, Clark M, et al. Pandemic (H1N1) 2009 Influenza in Australia: absenteeism and redeployment of emergency medicine and nursing staff. Emerg Med Australas. 2011:23(5):615-23. https://doi.org/10.1111/j.1742-6723.2011.01461.x.

20. Serrano-Ripoll MJ, Meneses-Echavez JF, Ricci-Cabello I, Fraile-Navarro D, Fiol-deRoque MA, Pastor-Moreno G, et al. Impact of viral epidemic outbreaks on mental health of healthcare workers: a rapid systematic review and meta-analysis. J Affect Disord. 2020;277:347-57. https://doi.org/10. 1016/j.jad.2020.08.034.

21. Wu P, Fang Y, Guan Z, Fan B, Kong J, Yao Z, et al. The psychological impact of the SARS epidemic on hospital employees in China: exposure, risk perception, and altruistic acceptance of risk. Can J Psychiatry. 2009;54(5):302-11. https://doi.org/10.1177/070674370905400504.

22. Gilbody S, Richards D, Brealey S, Hewitt C. Screening for depression in medical settings with the patient health questionnaire (PHQ): a diagnostic meta-analysis. J Gen Intern Med. 2007;22(11):1596-602. https://doi. org/10.1007/s11606-007-0333-y.

23. McManus D, Pipkin SS, Whooley MA. Screening for depression in patients with coronary heart disease (data from the Heart and Soul Study). Am J Cardiol. 2005;96(8):1076-81. https://doi.org/10.1016/j.amjcard.2005.06. 037.

24. Kroenke K, Spitzer RL, Williams JB. The Patient Health Questionnaire-2: validity of a two-item depression screener. Med Care. 2003:41(11):128492. https://doi.org/10.1097/01.MLR.0000093487.78664.3C.

25. National Institute for Occupational Safety and Health. Hierarchy of Controls. 2015. Atlanta (GA): Centers for Disease Control and Prevention. https://www.cdc.gov/niosh/topics/hierarchy/default.html. Accessed 18 September 2020

26. Possamai MA. SARS and health worker safety: lessons for influenza pandemic planning and response. Healthc Pap. 2007;8(1):18-28. https://doi. org/10.12927/hcpap.2007.19354.

27. Reopening Massachusetts. 2020. https://www.mass.gov/doc/reopeningmassachusetts-may-18-2020/download. Accessed 18 September 2020.

28. Levitz J. Massachusetts ranks third among states with most coronavirus cases. Wall Street J. 2020. https://www.wsj.com/articles/massachusettsranks-third-among-states-with-most-coronavirus-cases-11587211201. Accessed 18 Sept 2020.

29. Lee AM, Wong JG, MCAlonan GM, Cheung V, Cheung C, Sham PC. Stress and psychological distress among SARS survivors 1 year after the outbreak. Can J Psychiatry. 2007;52(4):233-40.

30. Maunder RG, Lancee WJ, Balderson KE, Bennett JP, Borgundvaag B, Evans S. Long-term psychological and occupational effects of providing hospital healthcare during SARS outbreak. Emerg Infect Dis. 2006;12:1924-32.

31. Maunder RG. Was SARS a mental health catastrophe? Gen Hosp Psychiatry. 2009;31(4):316-7. https://doi.org/10.1016/j.genhosppsych.2009.04. 004.

32. Wahlster S, Sharma M, Lewis AK, Patel PV, Hartog CS, Jannotta G, et al. The coronavirus disease 2019 pandemic's effect on critical care resources and health-care providers: a global survey. Chest. 2021;159(2):619-33.

33. Chungong S, Choupe LBT, Ho MZJ, Nuzzo J, Brown GW, Kandela N. Health systems for health security — strengthening prevention, preparedness and response to health emergencies. Wkly Epidemiol Rec (published by the World Health Organization). 2021;96:157-164. https://www.cente rforhealthsecurity.org/our-work/publications/health-systems-for-healthsecurity--strengthening-prevention-preparedness-and-response-tohealth-emergencies

34. Kahaleh AA, Truong H-A. Applications of the health belief model and continuing professional development for emergency preparedness and response. Am J Pharm Educ. 2021;85(1):8376.

35. Ghawadra SF, Abdullah KL, Choo WY, Phang CK. Mindfulness-based stress reduction for psychological distress among nurses: a systematic review. J Clin Nurs. 2019;28(21-22):3747-58.

36. Dossett ML, Needles EW, Nittoli CE, Mehta DH. Stress Management and resiliency training for healthcare professionals: a mixed-methods, qualityimprovement, cohort study. J Occup Environ Med. 2021;63(1):64-8.

37. Riley JM, Collins D, Collins J. Nursing students' commitment and the mediating effect of stress. Nurse Educ Today. 2019;76:172-7.

38. Hsu H-C, Wang P-Y, Lin L-H, Shih W-M, Lin M-H. Exploring the relationship between professional commitment and job satisfaction among nurses. Workplace Health Saf. 2015;63(9):392-8.

39. Dooley SW, Frieden TR. We must rigorously follow basic infection control procedures to protect our healthcare workers from SARS-CoV-2. Infect Control Hosp Epidemiol. 2020;41(12):1438-40. 
40. Marcus C. Strategies for improving the quality of verbal patient and family education: a review of the literature and creation of the EDUCATE model. Health Psychol Behav Med. 2014;2(1):482-95. https://doi.org/10. 1080/21642850.2014.900450.

41. Murray MK. The nursing shortage. Past, present, and future. J Nurs Adm. 2002;32(2):79-84. https://doi.org/10.1097/00005110-200202000-00005.

42. Rolin SN, Flis A, Davis JJ. Work coping, stress appraisal, and psychological resilience: reaction to the COVID-19 pandemic among health care providers. Psychol Neurosci. 2021. https://doi.org/10.1037/pne0000257.
43. Manzano García G, Ayala Calvo JC. The threat of COVID-19 and its influence on nursing staff burnout. J Adv Nurs. 2021;77(2):832-44.

\section{Publisher's Note}

Springer Nature remains neutral with regard to jurisdictional claims in published maps and institutional affiliations.
Ready to submit your research? Choose BMC and benefit from:

- fast, convenient online submission

- thorough peer review by experienced researchers in your field

- rapid publication on acceptance

- support for research data, including large and complex data types

- gold Open Access which fosters wider collaboration and increased citations

- maximum visibility for your research: over $100 \mathrm{M}$ website views per year

At BMC, research is always in progress.

Learn more biomedcentral.com/submissions 